\title{
フロセマイドによると思われた難聴の症例
}

\author{
盛岡赤十字病院耳舅咽搌科 \\ 南吉眾 \\ 岩手医科大学耳舆咽喉科学教室（主任：立木 孝教授） \\ 根本 聰彦
}

\section{A CASE OF HEARING LOSS PRESUMABLY INDUCED BY FUROSEMIDE}

YOSHINORI MINAMI, M. D.

Department of Otorhinolaryngology, Morioka Red Cross Hospital, Morioka

Satohiko Nemoto, M. D.

Department of Otorhinolaryngology, Iwate Medical University, School of Medicine, Morioka

The patient was a 76-year-old female. Because of heart disease she was administered on 40mg tablets of furosemide, a loop diuretic at the department of internal medicine. During taking furosemide, she noticed bilateral hearing loss, which developed into profound deafness. Therefore furosemide was withdrawn, and started treatment of steroid (Rinderon), Methycobal ${ }^{\circledR}$ and other drugs which were considered appropriate for acute sensorineural deafness. As a result, her hearing recovered. The authors described the course of deafness in this case and reviews in the literature. A search of the literature reveals no clinical case of furosemide-induced deafness in Japan, but in Western countries the following three characteristics of furosemide-induced deafness have been revealed. Briefly, (1) it is liable to occur after an intravenous bolus of 1,000 to $2,000 \mathrm{mg}$; (2) hearing loss often occurs immediately or 10 to $20 \mathrm{~min}$. after intravenous administration of the drug; and (3) the disturbance is generally transient, reversible sensorineural deafness that improves toward normal in 4 to 5 hours. Furthermore, the following three factors are considered to be related to the onset of furosemide ototoxicity; (1) dose per unit time, (2) severe renal function impairment, and (3) coadministration of furosemide and an aminoglycoside antibiotics. However, our patient was negative for renal function impairment and aminoglycoside antibiotics, and developed severe deafness after usual oral doses of furosemide. As compared to cases thus far described in the literature, our patient can be considered rather exceptional.

\section{I 楮言}

フロセマイド袙，1964年 Strum らにより開発された 㙁類排泄性利尿剂で，従来のサイアザイド系利氺剤汇比

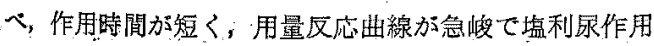

が強いことや，同じループ利沓郕であるエタクリン酸が 踾器毒性が強く，余使用されなくなっているのに反し， 近年臨床上類用されているフロセマイドの耳毒性につい

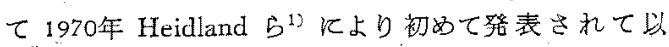




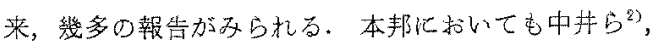

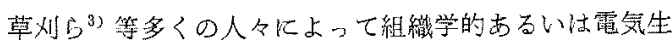
理学的に述べられているが，実際の陪休例几ついての報

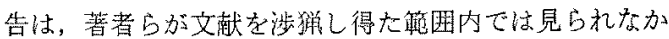
った、今回我々は，経口的にフロセマイド錠 (40mg) を 連日服用中に難㯖を訴光た症例を経鮯し，聴力の経過を 追跡し得たので，その結果について述べると共に文献的 考察を加えて啹台する。

$$
\text { II 症例 }
$$

症例: 76蒜，女性.

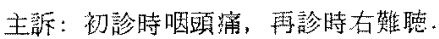

現病歴：昭和59年2月6日上り心疾婁にて内科入院. 2 月末頃より咽頭痛, 耳痛およびしばしば $37^{\circ} \mathrm{C}$ 台の発 熱を培えるため3月1日当科索受診した。難㯖・耳鳰な

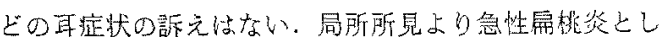

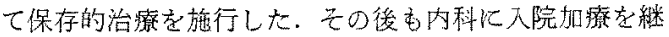

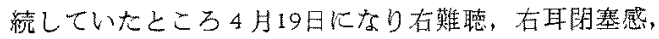
右耳自声強聴を訴えるようになったしの時点で再度詳 細に問診したとこる2月末頃より難聴实味であったとい ろ)。耳鳴はない。

経過：4月19日再診時局所所見では，鼓膜は在光錐短 缩，左正常、䙹，咽頭，喉頭には特記すべき異常所晃は 熟められない。

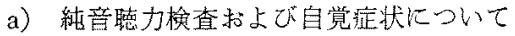

純音聴力検查の結果は图 1 に示したごとくて，雨則感 音性難聴の他に右耳儿伝音障憲放加味さ扎ていることが 認められ九．外来にて通氛療法を施行していたが，5月

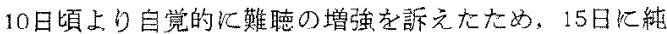

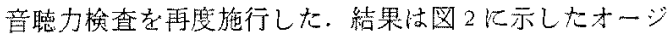
オグラムのごとくに㯖力の覀化が認められた，そこで通 橆の他にメチコバール，ユベラニコチネートなどの檠物 療法を古併用した，5月31日内科退院後，6月14日迄前述 薬物索腿用していた，その後来科しなくなったため服桨 を一時山断していたとこる，18日より更に難聴の增鲁傾

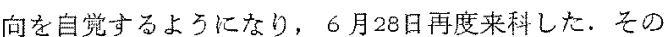

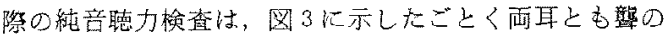

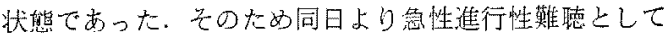
前述の浆物の他にリンデロン（4 mg より漸减療法）を経 口的飞投与し，外来にて経過観祭した，その後の自党 症状の変化は表 1 に示した。 リンデロン投与開始後4日 目頃より自覚的《聴力の改善が証められるようになり， 7 月 3 日朝 6 時起床後より家人の涪が分かる程度に聴力

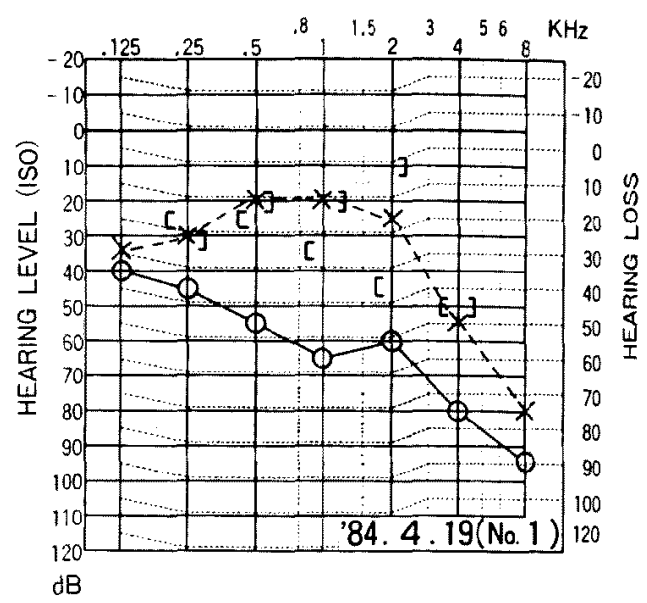

図 1 初回オージオグラム（1984，4，19）

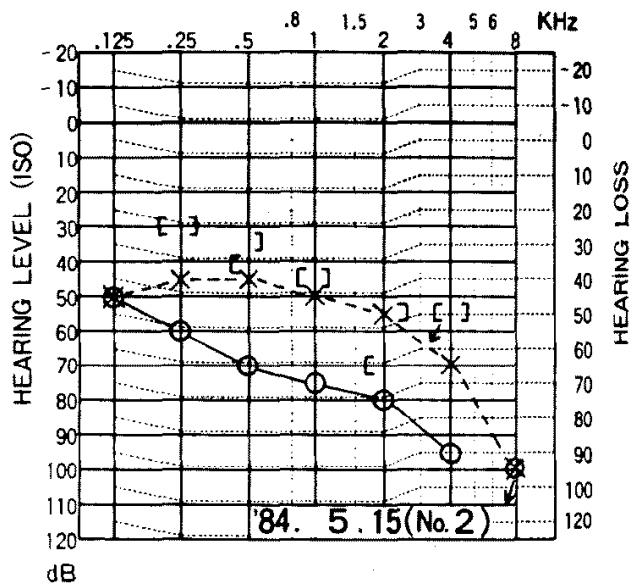

図 2 オージオグラム $(1984$ ，5，15)

は改善した。この時点で 2月8日よりフロセマイト缤 (40mg) 速日午前 7 時飞 1 錠服用してい西事が判明し

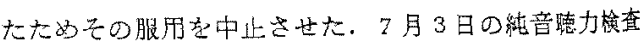
結果は图4のa）のごとく回復傾向を示して蚂，その 後図 40 b)，c）のごとくに更に徐々に回復した.

b) 自記オージオメトリーKついて

聴力が改善し始めた 7 月3日より自記オージタメトり 一(困 5) を施行し，同法にての経過を観察した。图 5

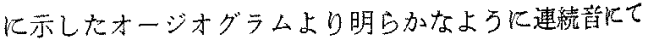
振幅小がみられ，Jerger II 型であった。，その後の代表

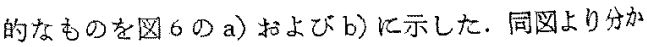




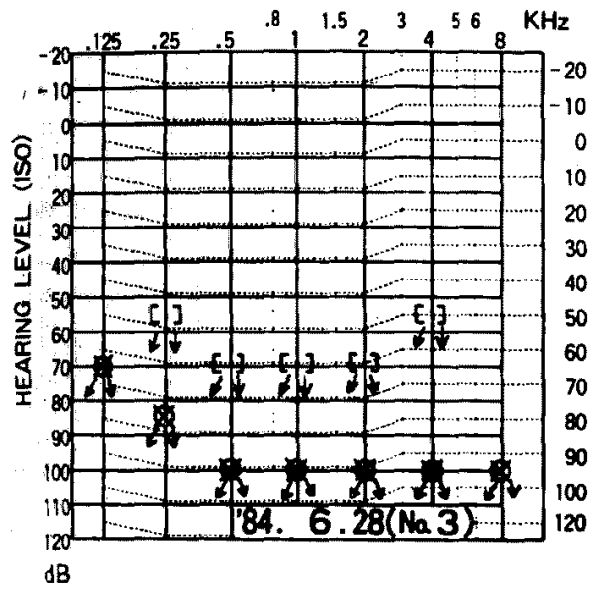

図 3 オージオグラム(1984、6. 28)

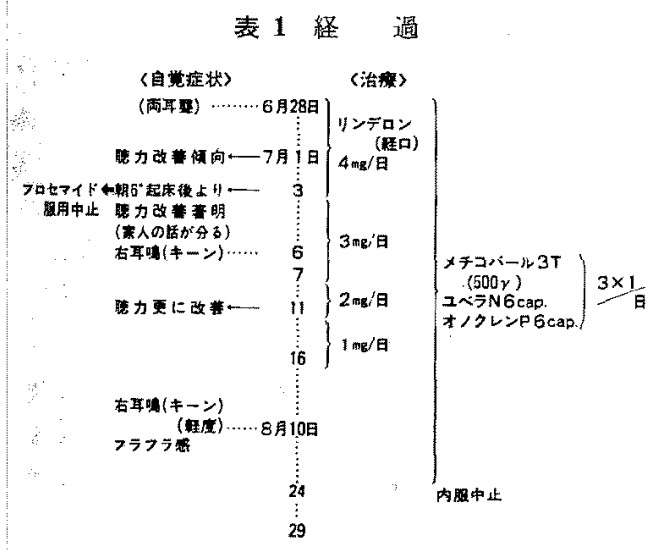

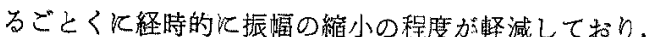
8月29日D検相ではほほ Jerger I 型腹している.

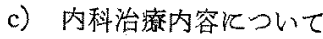

2月6日k内科入院後に使用された薬郕は表 2 飞示し た。この中で神来より耳毒性を指摘されているものは， ループ利泿剮であるフロセマイド錠 (40mg) のみであ

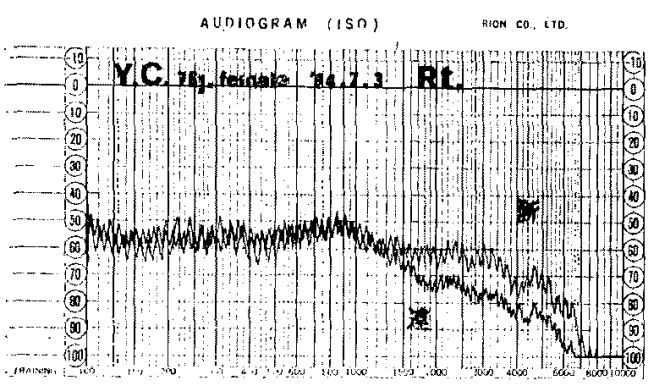

TOKXOQ JAPAA

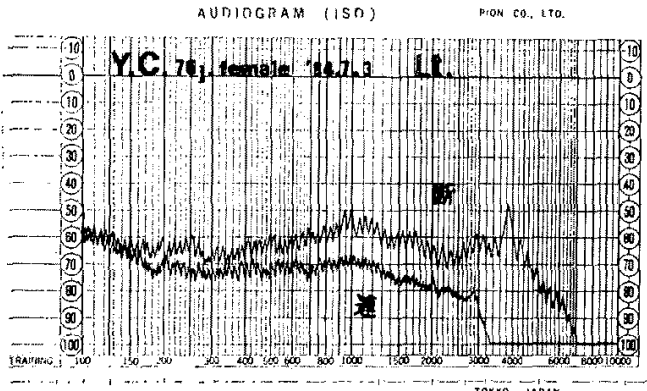

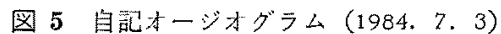
上図:右耳 下図:左耳

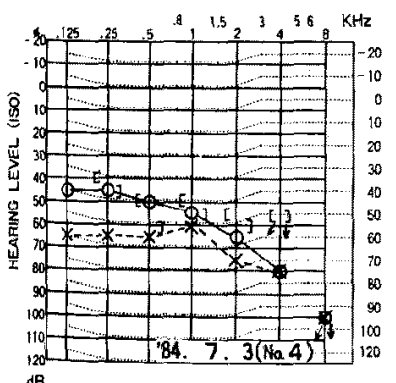

(a) $1984,7.3$

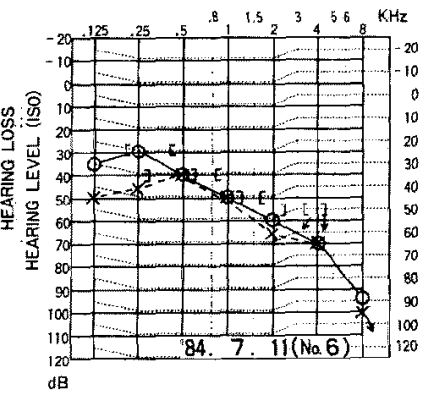

(b) 1984.7.11

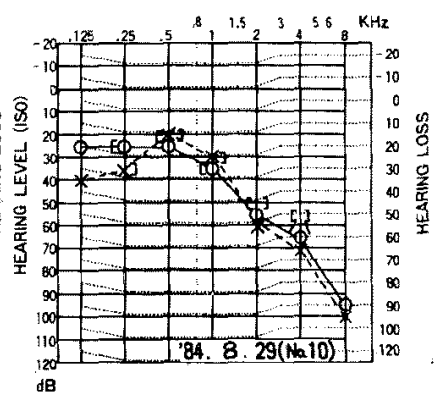

(c) $1984,8,29$

図4オージオグラム 
(古 耳)

AUfJIORAM (IST)

(a)

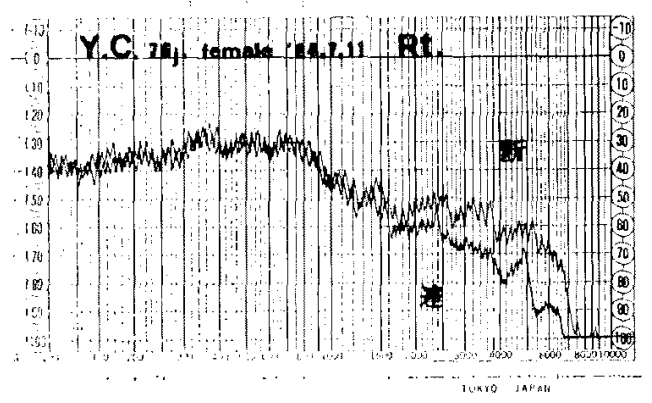

- riserf c0. 519.

(b)

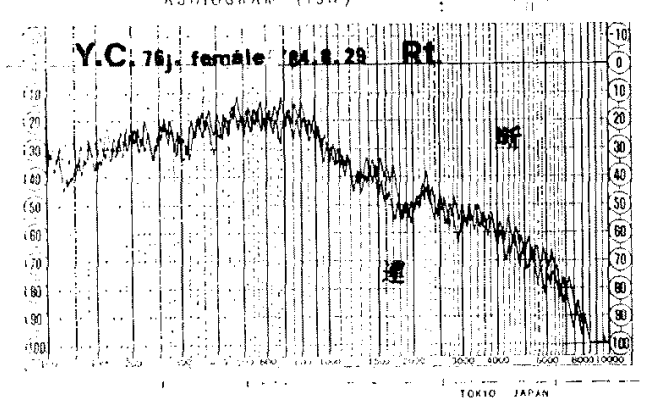

図 6 自塥オージオグラム

(a): 1984.7.11

表 2 内科治療内容

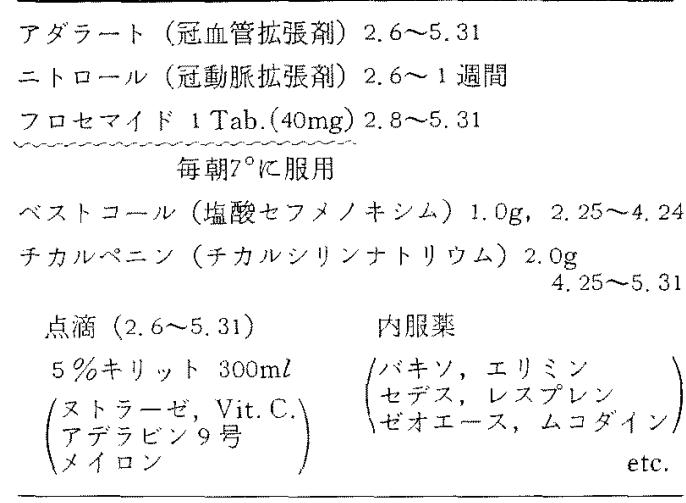

り，フロセマイド錠注，2月8日より服用を中止した7 月 2 日迄遇日1鉝服用されていた。内料入院中心諸梚查 では，又院然初の2 日間法若丁尿量が少なかった(350 $700 \mathrm{ml})$ が，艺心後は約 $1000 \sim 2000 \mathrm{ml}$ でり，血液学 的, 血液生化学的, 留機能捈査なじに打いて子異常は認 められていない。

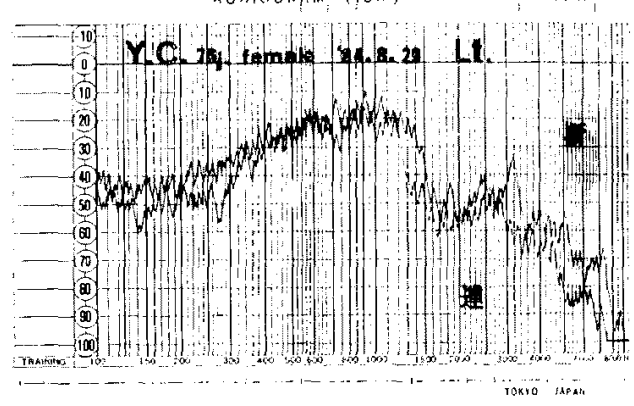

(b) : 1984. 8. 29

(左 耳)

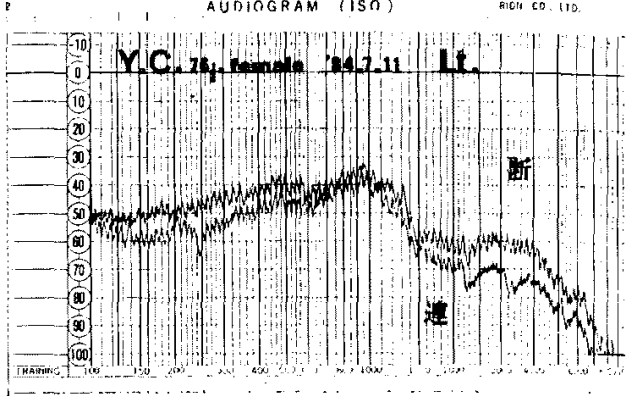

iirio is: in:

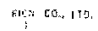

\section{III 考按}

フロセマイドと同じループ租尿戍であるエタクリン酸

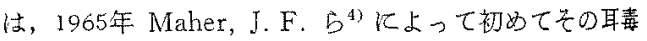
性飞ついての報告がなされて格り，それ以来数多くの摯 告か子られるようになり，乙の聴器毒性が強い亭より， 最近で估エ夕クリン酸に加わってフロセマイドが政床上 繁用さ犳るようになってきた。エタクリン酸と阔じルー

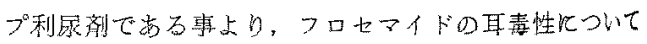
は当初より㞣惧されていたが，1970年 Heidland $b^{1 か ゙ ~}$

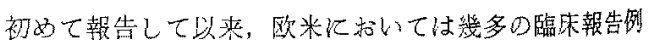
がみられる。しかし本邦化いては我々が文献索涉消し

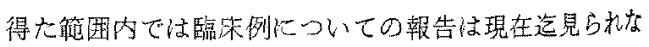
い，組織学的または電夋生理学的には，同じループ利尿

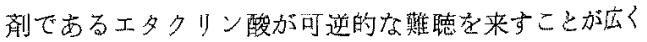
知られ，内耳性難璃の病態索知るのに好都合な大め多く の実驗的報告がなされているのし同じくフロセマイト ついても多くの人々により詳細に検討されている。本邦

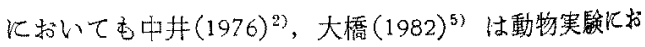
いてフロセマイドよる变化は，螖牛血管条辺縁細胞表 


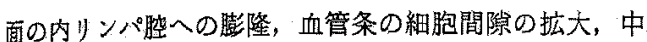
間細胞の萎縮などが特長的所見であり，通常の血管条の 内リンパ分䎵作用が正常に営密れていない状热を示し， また血管条の変性はラセン器の変性炕先行して発生し, 加ラセン器の変化は軽铰であると述へている。電気生 理学的には; フロセマイドをモルモットル大量竫注した

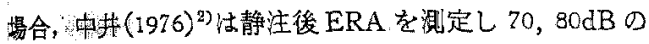
音刺激汇対して無反応であったものが，1時閐後には正 常化国復した事を述へている. 更下 Mathog 5(1970)6),

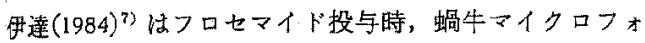
以電位だけでなく，EP も低下することを，また，草刚 B(1978) ${ }^{3)}$ は EP の低下が速やかであり，その障害は大 量投与です1〜2時間後には投与前のレバルに运回復す ることを示し，フロセマイドによる難聴が動物実験上で 法一過性の可逆性障害であることを示晙している。これ

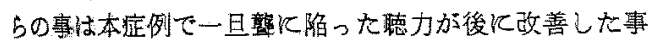
より臨床的飞も領ける事柄と考えられる。

欧米の実際の臨床例の報告についてみると, Heidland らはフロセマイド $1000 \mathrm{mg}$ 40分以内 (25mg/分)で 静注投与した例では15名中9名に中・高音域の可逆性 㮦力障害吕，600 $\mathrm{mg}$ 10名中 4 名に轻度の可选性の難聴が見られたが，経口あ るいは最高 5〜6mg/分のスピードで静注投与した 10名 では大量のフロセマイドです何ら副作用は認められなか

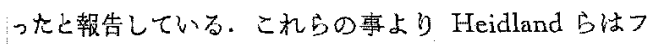
ロセマイドによる難聴の発症は dose/time の商の大き さが関係しているのではないかと結論し，フロセマイト の投与量は $4 \mathrm{mg} /$ 分の籍用内にて行うべきである事を提

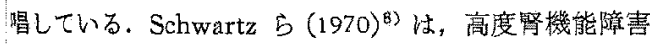
者5名にフロセマイドを 800〜2000mg 静沬したとこる，

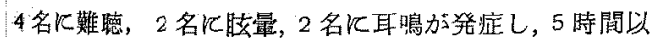
内浣全江回復したと述べ，フロセマイドの副作用は一

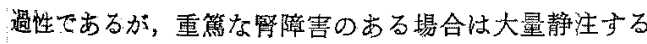

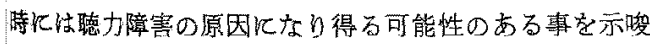
している.Vargish ら (1970) 浪尿毒症で治潦中の32歳 の男珄にフロセマイドを経口的に濑増投与し $3.0 \mathrm{~g}$ 迄增 量したが效果がないために静注投与に変更, 初日 $200 \mathrm{mg}$ を结明简飞6回投与，2日目は 400mg 增量，2時間 每に3回投与したところこの日の3回目の投与後30分で脑

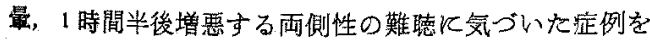

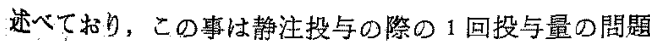
安提起していると考光られる.Venkateswaren $(1971)^{10)}$

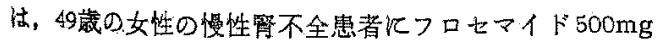

を3 分で静注後間もなく難焾に気づいたが，1時間後に

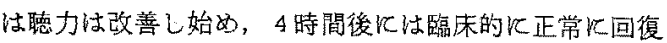
した症例を経驗した，翌日同量を同様に投与したとこる 再度前日と同様の経過を呈したが，同症例飞対しつロ七 マイドを $240 \mathrm{mg}$ として5分間で投与したとこる耳症状 の発現は誌められなかったと述べている。この事は前述 ○ Heidland bと同样k dose/time の值方耳毒性発現 の要因である裹を示唆していると教えても差し支点ない と思われる. Lloyd-Mostyn Б (1971) ${ }^{11}$ は，慢性心疾 患患者住対しフロセマイドを240mgを2度，2日䦎急

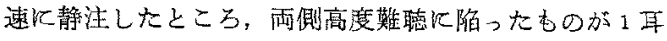
は Z週間の閏に徐々に回復したのに反し，他耳は永綕性 難聴のままであった症例老報告し，場合によっては一過 性障害でなく恒久的障害が起こる嘉むあり得る事を初め て示した. 更に Bourke (1976) は2 はフロセマイドを使

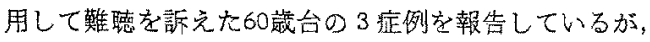
その投与量山 $240 \mathrm{mg}, 160 \mathrm{mg}$, $500 \mathrm{mg}$ と比較的少量で あった。その中で $160 \mathrm{mg}$ 投与例は投与後90分で完全飞

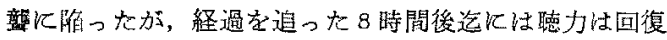
しなかったと述へている。このように多くの報告例で は，乙の障害证一過性のものが王倒的飞多く，恒久的な 障害は前述の埌告中では 2 例しかみられないのK比し， Quick ら (1975) ${ }^{13)}$ はっセマイド使用後に発症した永

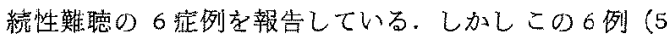

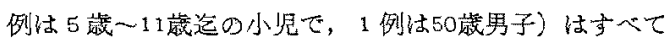
が重镭な緊疾患で両側腎摘出招上び脾摘出を施行され，

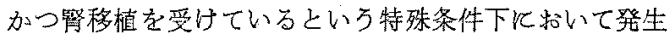
している点が前述の報告とは異なり特徵的である，従来

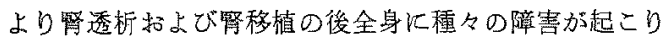
得，聴党系に予期せぬ異常が起こり得各事は知られて いることであり，特に Quick らの医療施設においては，

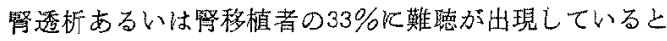

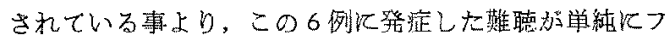

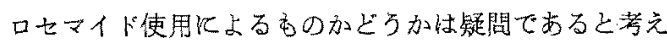
られる.以上のような欧米炕扔ける隐床例よりをのフロ

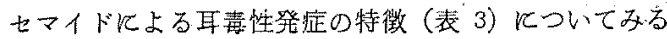
そ，1）1000 2000mg とい弓大量静注投与時江発症し 易い，2）発症する㯖力障害は静注㗐後より10２0分後 位に発症する事が多い，3）障害は 4 〜 時間で回復す

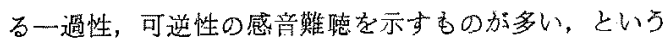
点が若えられ，かつ耳毒性発現の要因（表 4）として考 えられるものとしては，一つには投与量とその注入時 間，方なわち単位時閻内に和ける投与量方閶題であると 
表 3 フロセマイドの耳毒性の特徵 (文嗝上の臨床例飞和いて)

投与量：1000mg 2000mg 以上の竫注

発 症: 注入後〜10 or 20 分以内に発拉 1 時閒で 回復傾向示し，4 or 5 時閥で正常飞復す

陪 䓙: 一過性

表 4 耳童性発現の要因

○投与量と時間（注入速度）

○高度の督機能障害（督透析 or 督移椎）

○ミ/配糖体抗生剂との僧用

考光られ，Heidland b静注の場合飞は投与量は 1 分 間に $4 \mathrm{mg}$ 以下にす心゙きであると提唱している。その他 高度督㙨能障害を有する場合やアミ／配糖体抗生剂を併 用する場合には，少量でもその相乘作用により㯖力障害 が登生しやす倳が挙げられている. Coopermann b $(1973)^{14)}$ は，午の諭文中で正常婜機能者氏エ夕タリン 酸 $50 \mathrm{mg}$ 童投与して難聴が発症した2例は之の2例とも に，アミ/配糖体抗生物䐝を併用していたと述心ている 事より，臨床上了ミ/配栯位生剂との併用は慎しまな くてはならない。

本症洌の㛫合には，前述の上うな腎機能障害屯なく， アミ/配糖体抗生物質との併用の睡往もなく，文献上で

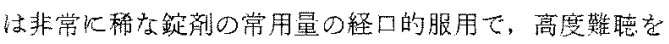
発症したという点で従棵の欧米の報告とは翼なり特異な 点であり，高㱓者の場合長期間にわたって反賃服用する

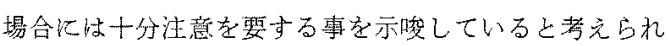
右.

難㜇発症の際の投与方法では静注に上石事が多いが経 口的投与によって発症したとする報告はフロセマイドの 場合火牥文献上見受けられず，著者の報告した本症例の みでるが，エタクリン酸の場合には，Schneider 5 $(1966)^{15)}$ が経口的に服用して一過性の難㯖になった症 例老, Pillay b $(1969)^{16)}$ 方永続性難㯖行なった症例を 報告しているので必ずしも経口的投与の場合は䋓対的に 安全であるとはいえないと思う。

治療は一般的には，フロセマイド使用学中止する事に より回復したとする報告が多いが，本症例のごとく進行 性で,かつメチコバールなどの腿薬老中断した後より雚

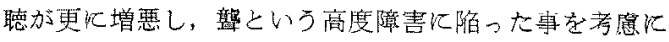

入れると，発宊後はフロセマイドの投与中止と共沉，高 度急性難㯖沉準じた治療を並行しなからら経過を䚁繁する こと加良いと考克られる。

\section{N 結語}

76藏，女性. 内科にて心疾患のため，ループ利疗剂て あるフロセマイド錠（40mg）を服用中に雨側難聴を挀

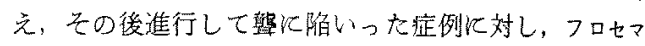
イド服用中止と其にステロイド(リンデロン),メチコパ

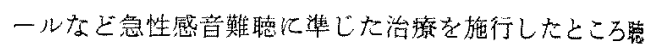
力回復を示した症例を経験したので，その聴力経過につ いて述へると共に，文献的考察を行って報告した. 本邦 に机いては，女献上フロセマイトによる難㯖登症の政床 洌は胃受けられないが，欧米の䇉告に上ると，その耳毒 性発症の臨床上の特徵としては，1）1000～2000 mg と いう大量静注投与時に発症し易い，2）発症する聴力障

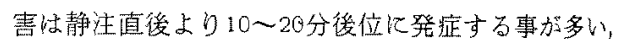

3）障等は 4〜5時間で回復する一過性，可逆性の感音嚾 聴を示す屯のが多いという3点であり，かつ耳毒性発現 の要因としては，1）単位時䦔内《和ける投与量，2）高

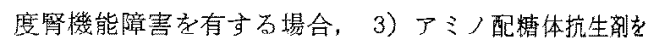
併用する場合が考光られる。本症例の場合は，督機能障 害やアミ，配糟体抗生剂の併用はなく，しか委常用量の 経口的服用で難㯖が発䆙，進行して哃度となったという 点文献上では特異的な列であると思われた。

\section{参考文 献}

1) Heidland $A$ et al: Einfuß hoher Furosemiddosen auf die Gehörfunktion bei Urämie. Klin Wochenschr 48: 1052-1056, 1970.

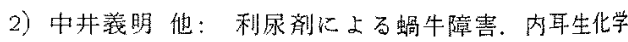
$7: 109-111,1976$.

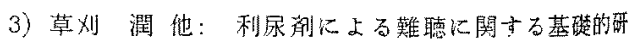
究. Audiology Japan 21: 117-122, 1978.

4) Maher JF et al: Studies on ethacrynic acid in patients with refractory edema. Ann Intern Med 62: 15-29, 1965.

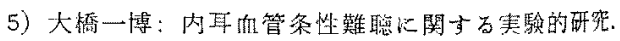
阪市医誌 31：697-711，1982,

6) Mathog RH et al: Ototoxicity of new and potent diuretics. A preliminary study. Arch Otolaryngol 92: 7-13, 1970.

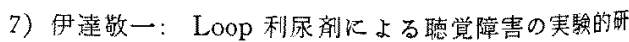




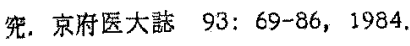

8) Schwartz GH et al: Ototoxicity induced by furosemide. New Engl J Med 282: 1413-1414, 1970.

9) Vargish $T$ et al: Deafness from furosemide. Ann Intern Med 72: 761, 1970.

10) Venkateswaren PS: Transient deafness from high doses of furosemide. British Med J 4: :13-114, 1971.

11) Lloyd-Mostyn $\mathrm{RH}$ et al: Ototoxicity of intravenous furosemide. Lancet 2: 1156-1157, 1971.

12) Bourke E: Furosemide, Bumetanide and Ototoxicity. Lancet 1: 917-918, 1976.

13) Quick CE et al: Permanent deafness associated with furosemide administration. Ann Otol 84: $94-101,1.975$.
14) Coopermann LB et al: Toxicity of ethacrynic acid and furosemide. American Heart Journal 85: 831-834, 1973.

15) Schneider WJ et al: Acute transient hearing loss after ethacrynic acid therapy. Arch Intern Med 117: 715-717, 1966

16) Pillay VK et al: Transient and permanent deafness following treatment with ethacrynic acid in renal failure. Lancet 1: 77-79, 1969.

稿を終克るにあたり御校閲下さいました恩師岩手医大 立木孝教授に感謝致します。な和本諭交の要旨は第12回 日本臨床耳科学会（於東京）にて笔表した。

（原禞受付 昭和60.4.27日 急戴)

別刷誈冰先 T020 篮岡枋中兴通口 1-2-1

盛岡赤十字病院耳竄咽喉科南吉昇 